\title{
Pyrenosetin D, a New Pentacyclic Decalinoyltetramic Acid Derivative from the Algicolous Fungus Pyrenochaetopsis sp. FVE-087
}

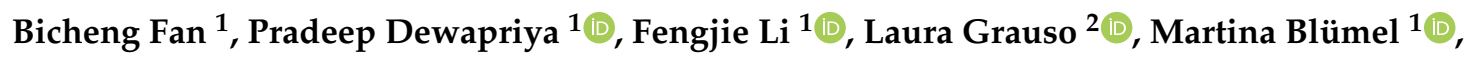 \\ Alfonso Mangoni ${ }^{3}(\mathbb{D})$ and Deniz Tasdemir ${ }^{1,4, *(D)}$ \\ 1 GEOMAR Centre for Marine Biotechnology (GEOMAR-Biotech), Research Unit Marine Natural Products \\ Chemistry, GEOMAR Helmholtz Centre for Ocean Research Kiel, Am Kiel-Kanal 44, 24106 Kiel, Germany; \\ bfan@geomar.de (B.F.); pdewapriya@geomar.de (P.D.); fli@geomar.de (F.L.); mbluemel@geomar.de (M.B.) \\ Dipartimento di Agraria, Università degli Studi di Napoli Federico II, via Università 100, 80055 Portici (NA), \\ Italy; laura.grauso@unina.it \\ 3 Dipartimento di Farmacia, Università degli Studi di Napoli Federico II, via Domenico Montesano 49, \\ 80131 Napoli, Italy; alfonso.mangoni@unina.it \\ 4 Faculty of Mathematics and Natural Sciences, Kiel University, Christian-Albrechts-Platz 4, \\ 24118 Kiel, Germany \\ * Correspondence: dtasdemir@geomar.de; Tel.: +49-431-600-4430
}

Received: 28 April 2020; Accepted: 24 May 2020; Published: 26 May 2020

\begin{abstract}
The fungal genus Pyrenochaetopsis is commonly found in soil, terrestrial, and marine environments, however, has received little attention as a source of bioactive secondary metabolites so far. In a recent work, we reported the isolation and characterization of three new anticancer decalinoyltetramic acid derivatives, pyrenosetins A-C, from the Baltic Fucus vesiculosus-derived endophytic fungus Pyrenochaetopsis sp. FVE-001. Herein we report a new pentacyclic decalinoylspirotetramic acid derivative, pyrenosetin $\mathrm{D}(\mathbf{1})$, along with two known decalin derivatives wakodecalines A (2) and B (3) from another endophytic strain Pyrenochaetopsis FVE-087 isolated from the same seaweed and showed anticancer activity in initial screenings. The chemical structures of the purified compounds were elucidated by comprehensive analysis of HR-ESIMS, FT-IR, $[\alpha]_{\mathrm{D}}, 1 \mathrm{D}$ and 2D NMR data coupled with DFT calculations of NMR parameters and optical rotation. Compounds 1-3 were evaluated for their anticancer and toxic potentials against the human malignant melanoma cell line (A-375) and the non-cancerous keratinocyte cell line (HaCaT). Pyrenosetin D (1) showed toxicity towards both A-375 and $\mathrm{HaCaT}$ cells with $\mathrm{IC}_{50}$ values of 77.5 and $39.3 \mu \mathrm{M}$, respectively, while 2 and $\mathbf{3}$ were inactive. This is the third chemical study performed on the fungal genus Pyrenochaetopsis and the first report of a pentacyclic decalin ring system from the fungal genus Pyrenochaetopsis.
\end{abstract}

Keywords: Pyrenochaetopsis; pyrenosetin; marine fungus; decalinoyltetramic acid; Fucus vesiculosus; anticancer

\section{Introduction}

Seaweeds harbor diverse microbial communities, such as bacteria, fungi, bacteriophage, and viruses, forming a complex holobiont [1-3]. Endophytic fungi are one of the predominant microbial communities associated with seaweeds and are gaining growing interest as a source of small molecule natural products with high chemical diversity and wide-ranging bioactivity profiles [4]. Over the past decades, several structurally unique metabolites from different classes of natural products, such as polyketides [5], terpenes [6], steroids [7], non-ribosomal peptides [8], and alkaloids [9] were 
reported from seaweed-derived (algicolous) fungi, with multiple bioactivities, including anticancer [7], antibiotic [9], and antioxidant [10].

Fungal metabolites with a 'decalin ring system' represent a large group of architecturally complex structural scaffolds [11]. The decalin ring system is usually substituted with, e.g., a terpene side chain [12] or $\gamma$-lactam [13], pyrone [14], diene [15], pyrrolizidine [16], and tetramic acid rings [17]. Decalin derivatives are also intriguing for their remarkable biological activities, including anticancer [18], antiviral [19], and antimicrobial [20]. So far, several decalin derivatives with multiple ring systems (e.g., tricyclic ring system [21]) or rare functional groups (e.g., deoxytetramic acid [17]) have been isolated from different algicolous fungi. As an example, Ascochyta salicorniae, an endophytic fungus derived from the green seaweed Ulva sp. yielded ascosalipyrrolidinones A and B, unusual decalin derivatives with an ether function on the terminal tetramic acid [17]. Ascosalipyrrolidinone A is a potent antiplasmodial agent that inhibits both the drug-resistant and the drug-sensitive Plasmodium falciparum strains $\mathrm{K}_{1}$ and $\mathrm{NF}_{54}\left(\mathrm{IC}_{50} 736\right.$ and $378 \mathrm{ng} / \mathrm{mL}$, respectively). It also shows antimicrobial and tyrosine kinase inhibiting activities [17].

As part of our on-going project aiming to investigate the cultivable mycobiome of seaweeds, we have previously isolated 55 epiphytic and endophytic fungi from the Baltic brown alga Fucus vesiculosus [22]. In-depth chemical investigation of the endophytic fungus Pyrenochaetopsis sp. FVE-001 by using a bioactivity-based molecular networking approach led to the rapid isolation and characterization of three new decalinoylspirotetramic acid derivatives pyrenosetins $\mathrm{A}-\mathrm{C}$ and the known decalin phomasetin [23]. All four compounds showed notable activity against human malignant melanoma cancer cells (A-375) [23]. In the continuation of our search for new anticancer metabolites from Fucus vesiculosis-associated fungi, a second strain of Pyrenochaetopsis sp. FVE-087 attracted our attention. In preliminary screenings, the crude extract of this strain also exerted potent anticancer activity [22]. Chemical work-up of this endophyte monitored by anticancer activity against the same melanoma cell line (A-375) resulted in the purification of a new pentacyclic decalinoyltetramic acid derivative, pyrenosetin D (1), along with two known decalins wakodecaline A (2) and wakodecaline B (3). In this study, we report the isolation, detailed structure elucidation, the anticancer activity, and the toxicity of compounds $1-3$.

\section{Results}

\subsection{Strain Identification and Cultivation}

The endophytic fungus FVE-087 (GenBank accession number: MH881502) was isolated from the inner thallus of the brown alga Fucus vesiculosus collected at Kiel Fjord (Baltic Sea, Germany). The initial taxonomic study of FVE-087 revealed its taxonomical identity at order level, i.e., Pleosporales [22]. The re-amplification of ITS1-5.8S rRNA gene-ITS2 region yielded a longer $408 \mathrm{bp}$ fragment, which enabled its identification at the genus level. A phylogenetic tree was constructed using the nucleotide sequences for related strains (obtained from NCBI database) including the previously identified Pyrenochaetopsis sp. FVE-001 from the same seaweed, indicating that the fungus FVE-087 was a close relative of the co-existing fungus Pyrenochaetopsis sp. FVE-001. Based on the phylogenetic tree analysis (Figure S1), the strain FVE-087 was confirmed to be a Pyrenochaetopsis sp. The fungus FVE-087 was cultivated in the same manner as described in our previous study [23], i.e., in liquid potato dextrose medium (PDM) at $22{ }^{\circ} \mathrm{C}$ for 14 days under continuous shaking.

\subsection{Extraction, Bioactivity Testing, and Isolation}

The culture broth $(24 \mathrm{~L})$ was extracted with EtOAc. The crude EtOAc extract of the fungus was subjected to a modified Kupchan partitioning scheme to yield $n$-hexane $(\mathrm{KH}), \mathrm{CHCl}_{3}(\mathrm{KC})$, and aqueous $\mathrm{MeOH}(\mathrm{KM})$ subextracts. All three subextracts were tested for their activity against five cancer cell lines; malignant melanoma (A-375), lung carcinoma (A-549), colorectal adenocarcinoma (HT-29), colorectal carcinoma (HCT-116), and breast cancer cell line (MDA-MB-231). The KC subextract showed the 
highest inhibitory activity against all tested cell lines (>84\% cell growth inhibition at $100 \mu \mathrm{g} / \mathrm{mL})$ and was selected for a detailed chemical work-up. The KC subextract was fractionated on a C18 SPE cartridge using a $10 \%$ gradient of $\mathrm{MeOH}$ in water. This yielded 11 subfractions, and the anticancer activity was tracked to late fractions 7-9 (Table S6). Reversed-phase HPLC purification of the fractions 7 and 8 , monitored by the anticancer activity against malignant melanoma (A-375) cells, afforded compounds 1-3 (Figure 1).
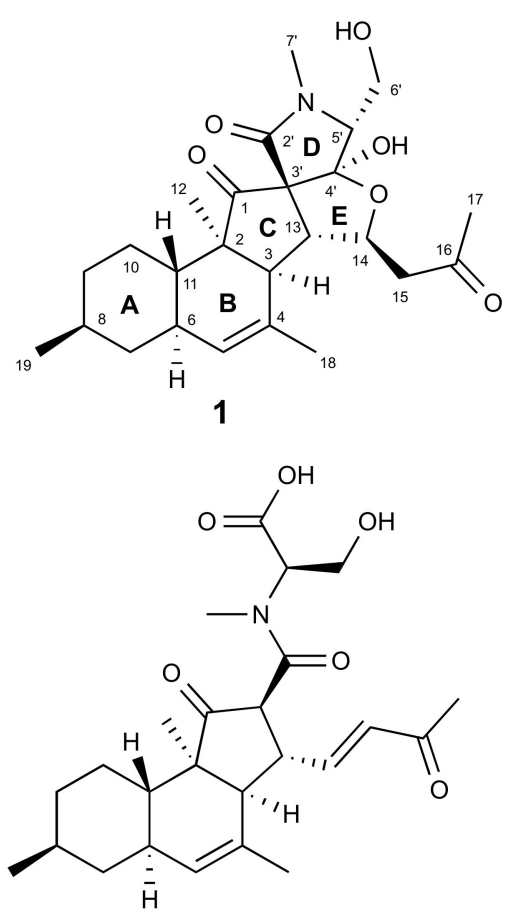

3
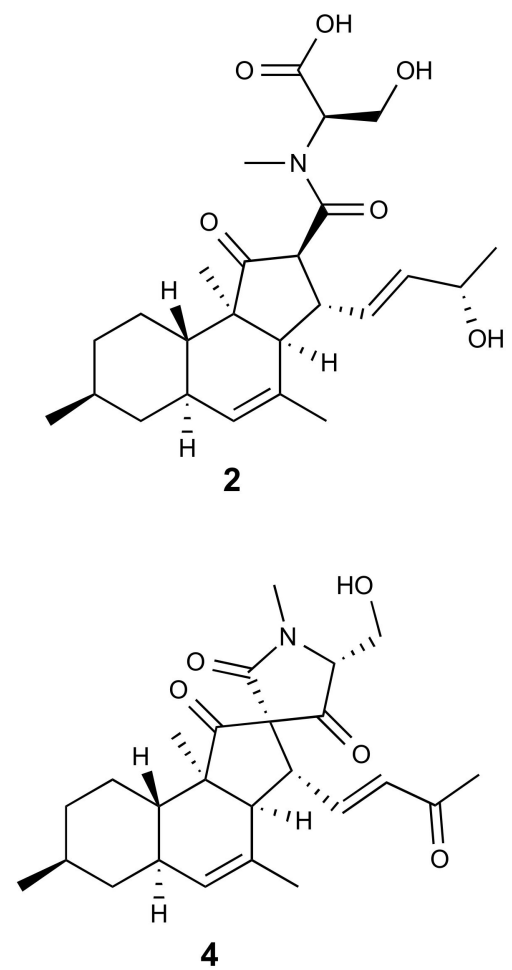

Figure 1. Chemical structures of compounds 1-4.

\subsection{Structure Elucidation}

Compound 1 was obtained as a colorless oil. The molecular formula $\mathrm{C}_{25} \mathrm{H}_{35} \mathrm{NO}_{6}$ that required nine degrees of unsaturation (DoU) was assigned based on the HR-ESIMS spectrum of 1 (Figure S10). The FT-IR spectrum (Figure S11) indicated the presence of hydroxyl $\left(v_{\max } 3226-3560 \mathrm{~cm}^{-1}\right)$, carbonyl $\left(v_{\max } 1679\right.$ and $\left.1734 \mathrm{~cm}^{-1}\right)$ and aliphatic ether $\left(v_{\max } 1064\right.$ and $\left.1159 \mathrm{~cm}^{-1}\right)$ functions. Comprehensive analysis of the ${ }^{1} \mathrm{H}$ NMR data in conjunction with the DEPT-HSQC spectrum $\left(\mathrm{CD}_{3} \mathrm{CN}\right.$, Table 1 , Figures S4 and S6) revealed the presence of five methyl groups, including one secondary $\left(\mathrm{H}_{3}-19, \delta_{\mathrm{H}}\right.$ $0.89, \mathrm{~d}, J=6.6 \mathrm{~Hz})$, one tertiary $\left(\mathrm{H}_{3}-12, \delta_{\mathrm{H}} 0.88, \mathrm{~s}\right)$, one olefinic $\left(\mathrm{H}_{3}-18, \delta_{\mathrm{H}} 1.76\right.$, br s), one methylketone $\left(\mathrm{H}_{3}-17, \delta_{\mathrm{H}} 2.09, \mathrm{~s}\right)$, plus an $N$-methyl $\left(\mathrm{H}_{3}-7^{\prime}, \delta_{\mathrm{H}} 2.86, \mathrm{~s}\right)$ signal. In addition, also observed were five pairs of diastereotopic methylene protons, namely $\mathrm{H}_{2}-7\left(\delta_{\mathrm{H}} 0.75, \mathrm{q}, J=11.9 \mathrm{~Hz}\right.$ and $\left.1.82, \mathrm{~m}\right), \mathrm{H}_{2}-9\left(\delta_{\mathrm{H}}\right.$ $0.83, \mathrm{dq}, J=2.7,12.6 \mathrm{~Hz}$ and $1.71, \mathrm{~m}), \mathrm{H}_{2}-10\left(\delta_{\mathrm{H}} 1.02, \mathrm{~m}\right.$ and $\left.1.29, \mathrm{dq}, J=12.9,3.0 \mathrm{~Hz}\right), \mathrm{H}_{2}-15\left(\delta_{\mathrm{H}} 2.52\right.$, $\mathrm{dd}, J=16.2,9.4 \mathrm{~Hz}$ and $\left.\delta_{\mathrm{H}} 2.70, \mathrm{dd}, J=16.2,3.1 \mathrm{~Hz}\right)$, and the oxymethylene protons of $\mathrm{H}_{2}-6^{\prime}\left(\delta_{\mathrm{H}} 3.79\right.$, $\mathrm{dd}, J=11.6,6.4 \mathrm{~Hz}$ and $\left.\delta_{\mathrm{H}} 3.86, \mathrm{dd}, J=11.6,4.1 \mathrm{~Hz}\right)$. The ${ }^{1} \mathrm{H}$ NMR spectrum also comprised signals belonging to eight methine protons; this included six aliphatic methine protons which were assigned to H-3 $\left(\delta_{\mathrm{H}} 2.32, \mathrm{~d}, J=10.0 \mathrm{~Hz}\right), \mathrm{H}-6\left(\delta_{\mathrm{H}} 1.84, \mathrm{~m}\right), \mathrm{H}-8(1.44, \mathrm{~m}), \mathrm{H}-11(1.48, \mathrm{ddd}, J=11.8,10.5,2.7 \mathrm{~Hz})$, $\mathrm{H}-13\left(\delta_{\mathrm{H}} 2.67, \mathrm{dd}, J=10.1,3.4 \mathrm{~Hz}\right), \mathrm{H}-5^{\prime}\left(\delta_{\mathrm{H}} 3.44, \mathrm{dd}, J=7.0,4.1 \mathrm{~Hz}\right)$, plus one olefinic methine proton that appeared as a broad singlet at $\delta_{\mathrm{H}} 5.25(\mathrm{H}-5)$ and an oxymethine proton that resonated at $\delta_{\mathrm{H}} 4.90$ $\left(\mathrm{H}-14, \mathrm{dt}, J=9.3,3.3 \mathrm{~Hz}\right.$ ) (Table 1). The ${ }^{13} \mathrm{C}$ NMR spectrum of $\mathbf{1}$ (Table 1, Figure S5) contained 25 signals accounting for three carbonyls $\delta_{\mathrm{C}} 170.2\left(\mathrm{C}-2^{\prime}\right), 206.8(\mathrm{C}-16)$, and $213.2(\mathrm{C}-1)$, and two olefinic carbons at 
$\delta_{C} 128.0(C-5)$, and $133.2(C-4)$, accounting for four DoU. This indicated 1 to be a pentacyclic compound. Comparison of the NMR data of $\mathbf{1}$ with those of tetracyclic decalinoylspirotetramic acid derivatives pyrenosetins A-C [23] indicated close similarities. Thus, $\mathbf{1}$ was identified as a pyrenosetin-type decalinoylspirotetramic acid with an additional ring system.

Table 1. ${ }^{1} \mathrm{H}$ NMR $(600 \mathrm{MHz})$ and ${ }^{13} \mathrm{C}$ NMR $(150 \mathrm{MHz})$ data of compound $\mathbf{1}\left(\mathrm{CD}_{3} \mathrm{CN}\right)$.

\begin{tabular}{|c|c|c|c|}
\hline \multirow{2}{*}{ No. } & & \multicolumn{2}{|c|}{1} \\
\hline & & $\delta_{\mathrm{H}}$, mult $(J$ in $\mathrm{Hz})$ & $\delta_{C}$ \\
\hline 1 & & - & 213.2 \\
\hline 2 & & - & 56.4 \\
\hline 3 & & $2.32, \mathrm{~d}(10.0)$ & 54.8 \\
\hline 4 & & - & 133.2 \\
\hline 5 & & 5.25, br s & 128.0 \\
\hline 6 & & $1.84, \mathrm{~m}$ & 37.7 \\
\hline \multirow[t]{2}{*}{7} & eq & $1.82, \mathrm{~m}$ & 42.9 \\
\hline & ax & $0.75, \mathrm{q}(11.9)$ & \\
\hline 8 & & $1.44, \mathrm{~m}$ & 33.5 \\
\hline \multirow[t]{2}{*}{9} & eq & $1.71, \mathrm{~m}$ & 36.0 \\
\hline & ax & $0.83, \mathrm{dq}(2.7,12.6)$ & \\
\hline \multirow[t]{2}{*}{10} & eq & $1.29, \mathrm{dq}(12.9,3.0)$ & 25.8 \\
\hline & ax & $1.02, \mathrm{~m}$ & \\
\hline 11 & & 1.48, ddd $(11.8,10.5,2.7)$ & 37.9 \\
\hline 12 & & $0.88, \mathrm{~s}$ & 14.2 \\
\hline 13 & & 2.67, dd $(10.1,3.4)$ & 57.0 \\
\hline 14 & & $4.90, \operatorname{dt}(9.3,3.3)$ & 83.7 \\
\hline \multirow[t]{2}{*}{15} & $\mathrm{a}$ & 2.70, dd $(16.2,3.1)$ & 50.3 \\
\hline & $\mathrm{b}$ & $2.52, \mathrm{dd}(16.2,9.4)$ & \\
\hline 16 & & - & 206.8 \\
\hline 17 & & $2.09, \mathrm{~s}$ & 30.8 \\
\hline 18 & & 1.76, br s & 23.2 \\
\hline 19 & & $0.89, \mathrm{~d}(6.6)$ & 22.5 \\
\hline $2^{\prime}$ & & - & 170.2 \\
\hline $3^{\prime}$ & & - & 75.3 \\
\hline $4^{\prime}$ & & - & 110.3 \\
\hline $5^{\prime}$ & & $3.44, \mathrm{dd}(7.0,4.1)$ & 68.3 \\
\hline \multirow[t]{2}{*}{$6^{\prime}$} & a & 3.86, dd $(11.6,4.1)$ & 60.4 \\
\hline & $b$ & 3.79, dd $(11.6,6.4)$ & \\
\hline $7^{\prime}$ & & $2.86, \mathrm{~s}$ & 29.5 \\
\hline
\end{tabular}

In order to identify the position of the fifth ring system and the complete planar structure of $\mathbf{1}$, we undertook DQF-COSY and HMBC experiments. The ${ }^{1} \mathrm{H}-{ }^{1} \mathrm{H}$ COSY spectrum of 1 comprised three spin systems (a-c) (Figure 2A and Figure S7). The largest spin system (a) started with the olefinic proton $\mathrm{H}-5$ that coupled with $\mathrm{H}-6$, then included the methyl substituted cyclohexane moiety that terminated with the $\mathrm{H}-11$. The latter proton was in turn coupled with $\mathrm{H}-6$, while $\mathrm{H}_{3}-19$ coupled with $\mathrm{H}-8$, completing the structure of the ring $\mathbf{A}$ with a secondary methyl group attached at C-8. Further detected in the COSY spectrum was a short spin system (b) that corresponded to a hydroxyethyl group ( $\mathrm{H}-5^{\prime}$ to $\left.\mathrm{H}-6^{\prime}\right)$. The final proton network (c) covered the protons of $\mathrm{H}-3, \mathrm{H}-13, \mathrm{H}-14$, and $\mathrm{H}_{2}-15$ (Figure 2A and Figure S7). 
A

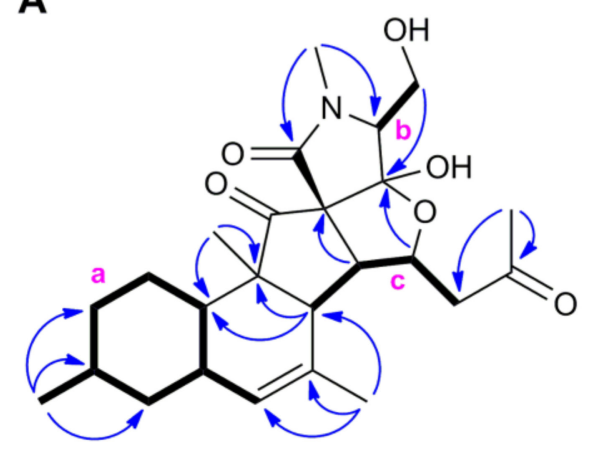

B

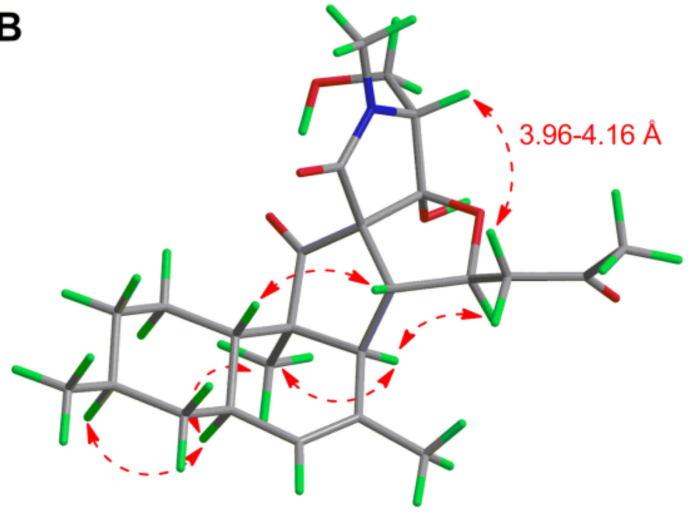

Figure 2. (A) Key COSY (bold) and HMBC (blue) correlations within 1. a-c: Spin systems extracted from the COSY spectrum. (B) NOESY (red) correlations on the lowest-energy DFT conformer of 1.

In-depth analysis of the ${ }^{1} \mathrm{H}-{ }^{13} \mathrm{C} \mathrm{HMBC}$ data (Figure $2 \mathrm{~A}$ and Figure S8) enabled to assemble the three COSY spin systems with quaternary carbons and heteroatoms, hence completing the full structure of 1. Firstly, the position of the $\mathrm{H}_{3}-19$ at $\mathrm{C}-8$ (ring $\mathbf{A}$ ) was further confirmed by the HMBC correlations between $\mathrm{H}_{3}-19$ with $\mathrm{C}-7, \mathrm{C}-8$, and $\mathrm{C}-9$. The ring $\mathbf{B}$ of the unsaturated decalin moiety was constructed on the basis of the HMBC cross-peaks observed from H-3 to C-2, C-4, C-5, and C-11, from H-5 to C-3 and $\mathrm{C}-11$, and from the olefinic methyl group $\mathrm{H}_{3}-18$ to $\mathrm{C}-3, \mathrm{C}-4$, and $\mathrm{C}-5$. The tertiary methyl $\mathrm{H}_{3}-12$ was assigned to $\mathrm{C}-2$ based on the key $\mathrm{HMBC}$ correlations from $\mathrm{H}_{3}-12$ to $\mathrm{C}-2, \mathrm{C}-3$, and $\mathrm{C}-11$. Additional HMBC correlations between $\mathrm{H}_{3}-12 / \mathrm{C}-1, \mathrm{H}-3 / \mathrm{C}-3^{\prime}$, and $\mathrm{H}-13 / \mathrm{C}-3^{\prime}$ confirmed the spiro (cyclopentanone) ring system $\mathbf{C}$ (Figure 2A). The ring $\mathbf{D}$ comprising of an $N$-methyl tetramic acid was built with the aid of the HMBC correlations between $\mathrm{H}-5^{\prime} / \mathrm{C}-2^{\prime}, \mathrm{H}-5^{\prime} / \mathrm{C}-4^{\prime}, \mathrm{H}-6^{\prime} / \mathrm{C}-4^{\prime}, \mathrm{H}-6^{\prime} / \mathrm{C}-5^{\prime}, \mathrm{H}_{3}-7^{\prime} / \mathrm{C}-2^{\prime}, \mathrm{H}_{3}-7^{\prime} / \mathrm{C}-5^{\prime}$. The upfield chemical shift of $C-4^{\prime}\left(\delta_{C} 110.3\right)$ in comparison to other pyrenosetins, such as pyrenosetin $C$ (4) suggested the presence in $\mathbf{1}$ of an acetal or hemiacetal rather than a ketone function. The connection of the ring $\mathbf{D}$ at $C-3^{\prime}$ of the ring $\mathbf{C}$ was evident due to further HMBC cross-peak seen between $\mathrm{H}-5^{\prime} / \mathrm{C}-3^{\prime}$.

Pyrenosetins A-C bear a C-16 oxygenated butyl substitution with a double bond $\Delta^{14(15)}$ in the side chain (attached at C-13) [23]. The comparison of the ${ }^{1} \mathrm{H}$ and ${ }^{13} \mathrm{C}$ NMR data of 1 from C-13 to C-15 (Table 1) with those of pyrenosetin C (4) [23] clearly showed that 1 lacks the double bond at $\mathrm{C}-14$. Instead, the $\mathrm{H}-14$ was converted to an oxymethine signal $\left(\delta_{\mathrm{H}} 4.90\right)$ that showed a diagnostic HMBC coupling with C-4' (Figure 2A and Figure S8). This fact, in addition to above mentioned COSY correlations between $\mathrm{H}-13 / \mathrm{H}-14$ and $\mathrm{H}-14 / \mathrm{H}_{2}-15$ confirmed the fifth tetrahydrofuran ring (E). Final HMBC correlations from $\mathrm{H}_{3}-17$ to $\mathrm{C}-15\left(\delta_{\mathrm{C}} 50.3\right)$ and $\mathrm{C}-16\left(\delta_{\mathrm{C}} 206.8\right)$ completed the side chain that ended with a methylketone. Thus, the pentacyclic $2 \mathrm{D}$ structure of $\mathbf{1}$ was established as shown in Figure 1.

The relative configuration of the stereogenic centers within 1 was deduced based on NOESY correlations and coupling constant analysis (Figure 2B and Figure S9). The two large axial-axial couplings experienced by $\mathrm{H}-11$ (ddd, $J=11.8,10.5$, and $2.7 \mathrm{~Hz}$ ) established the trans junction between rings $\mathbf{A}$ and $\mathbf{B}$. The observed NOESY correlations between $\mathrm{H}-3 / \mathrm{H}_{3}-12, \mathrm{H}-3 / \mathrm{H}-14, \mathrm{H}-6 / \mathrm{H}-8, \mathrm{H}-6 / \mathrm{H}_{3}-12$, and $\mathrm{H}-11 / \mathrm{H}-13$ indicated the $\alpha$-orientation of $\mathrm{H}-3, \mathrm{H}-6, \mathrm{H}-8, \mathrm{H}_{3}-12, \mathrm{H}-14$, and the $\beta$-orientation of $\mathrm{H}-11, \mathrm{H}-13$, and the $\mathrm{H}_{3}-19$ methyl group. This left three stereogenic centers $\left(\mathrm{C}-3^{\prime}, \mathrm{C}-4^{\prime}\right.$, and $\left.\mathrm{C}-5^{\prime}\right)$ in the tetramic acid moiety to be assigned.

Assignment of configuration at C $-3^{\prime}$ and $C-4^{\prime}$ was based on the high geometric strain of trans-5,5-fused ring systems, which are known to be less stable than their cis counterparts by more than $6 \mathrm{kcal} / \mathrm{mol}$ [24]. As the hemiacetal function at C-4' would readily open in case of steric strain, the possibility of strained trans junctions between rings $\mathbf{C}$ and $\mathbf{E}$ and/or between rings $\mathbf{E}$ and $\mathbf{D}$ was ruled out, and the requirement of cis junctions between rings $\mathbf{C}, \mathbf{E}$, and $\mathbf{D}$ defined configurations at 
C $-3^{\prime}$ and $C-4^{\prime}$ as depicted in structure 1 . The configuration at C-5' was suggested by a very weak NOE correlation between $\mathrm{H}-5^{\prime}$ and $\mathrm{H}-15 \mathrm{~b}\left(\delta_{\mathrm{H}} 2.52\right)$ (Figure $2 \mathrm{~B}$ ).

As the determined configuration at $\mathrm{C}-3^{\prime}$ was opposite to that found in the other pyrenosetin analogues (including compound 4), and configuration at $C-5^{\prime}$ was only based on a single weak NOE correlation, the structure of $\mathbf{1}$ was validated using DFT prediction of NMR parameters. Compound $\mathbf{1}$, its epimer at C-3', namely $3^{\prime}$-epi-1 (which has also opposite configuration at C-4' ${ }^{\prime}$, to keep the cis junction between rings $\mathbf{D}$ and $\mathbf{E}$ ), and its epimer at $\mathbf{C}-5^{\prime}$, namely $5^{\prime}$-epi-1 were considered for calculations (see Supplementary Figure S2 for structures, and Materials and Methods Section for details on computational methods). After a molecular dynamics-based conformational search, conformers were optimized at the B3LYP/TZVP/SMD level; then, ${ }^{1} \mathrm{H}$ and ${ }^{13} \mathrm{C}$ isotropic shieldings were calculated, respectively, at the WP04/aug-cc-pVDZ/PCM and mPW1PW91/6-311+G(2d,p) levels of theory, and scaled to chemical shifts using the linear regression method [25]. Calculations on $3^{\prime}$-epi-1 were soon stopped, because optimized conformers showed energies constantly higher than $\mathbf{1}$ by more than $10 \mathrm{kcal} / \mathrm{mol}$ (as expected, because of the strained trans junction between rings $\mathbf{C}$ and $\mathbf{E}$ ) and root-mean-square deviations (RMSD) of ${ }^{13} \mathrm{C}$ NMR chemical shifts of rings $\mathbf{C}, \mathbf{D}$, and $\mathbf{E}$ constantly over $6 \mathrm{ppm}$. In contrast, chemical shifts calculated for compound 1 were in excellent agreement with the experimental values (RMSD of $1.66 \mathrm{ppm}$ for ${ }^{13} \mathrm{C}$ and 0.076 for ${ }^{1} \mathrm{H}$ ). While this results provided solid support to the overall structure of $\mathbf{1}$ and to configurations at C-3' and C- $4^{\prime}$, they did not support the assignment of the configuration at $\mathrm{C}-5^{\prime}$, because chemical shifts of $5^{\prime}$-epi-1 also showed a comparable agreement with the experiment (RMSD of $1.69 \mathrm{ppm}$ for ${ }^{13} \mathrm{C}$ and $0.077 \mathrm{ppm}$ for ${ }^{1} \mathrm{H}$ ) (Figure S3). Even restricting the comparison to atoms of ring D and/or using DP4+ analysis [26], no clear-cut answer about configuration at $\mathrm{C}-5^{\prime}$ could be obtained from the predicted chemical shifts. Therefore, coupling constants were examined.

Analysis of structures $\mathbf{1}$ and $5^{\prime}$-epi-1 showed that the main difference between the two compounds was expected in the ${ }^{1} \mathrm{H}_{-}{ }^{13} \mathrm{C}$ coupling constants of $\mathrm{H}-5^{\prime}$. In particular, the coupling constant between $\mathrm{H}-5^{\prime}$ and $\mathrm{C}-2^{\prime}$ was calculated as $4.3 \mathrm{~Hz}$ for $\mathbf{1}$ and $0.6 \mathrm{~Hz}$ for $5^{\prime}-$ epi-1 (Table S5). When not measured directly, ${ }^{1} \mathrm{H}_{-}{ }^{13} \mathrm{C}$ coupling constants can be estimated from the intensity of the corresponding HMBC peaks, an intense peak indicating a relatively large $J_{\mathrm{CH}}$ [27]. The prominent correlation peak observed between $\mathrm{H}-5^{\prime}$ and $\mathrm{C}-2^{\prime}$ was not consistent with the small $0.6 \mathrm{~Hz}$ coupling constant predicted for $5^{\prime}$-epi-1, and conclusively determined the relative stereochemistry of pyrenosetin D as in structure 1 . Finally, the observed weak NOE correlation between $\mathrm{H}-5$ and $\mathrm{H}-15 \mathrm{~b}$ was in good agreement with the distance between 3.96 and $4.16 \AA$ of these protons measured for the DFT optimized conformers of $\mathbf{1}$ (Figure 2B).

The absolute configuration of compound 1 was determined on the basis of its predicted optical rotation (OR). DFT prediction of OR is a valuable, although not as general, alternative to ECD for determining the absolute configuration of natural products, and can be reliably used for this purpose provided that (i) the magnitude of the measured OR is not close to zero and (ii) the sign of the calculated OR is the same for all, or at least for most conformers [28]. The OR of compound 1 was predicted at the B3LYP/TZVP/PCM $(\mathrm{MeOH})$ level of theory; the calculated $[\alpha]_{\mathrm{D}}$ (as the Boltzmann average of individual conformers) was -104, compared to the experimental value -56 . In addition, the OR values calculated for individual conformers were all negative, and with similar magnitude. These results strongly supported the absolute configuration of pyrenosetin D as shown in Figure 1.

The known compounds 2 and 3 were identified as wakodecalines A and B (Figure 1), respectively, based on their HR-ESIMS and MS/MS data, plus by comparison of their 1D/2D NMR and $[\alpha]_{D}$ data with those reported in the literature [29].

\subsection{Bioactivity Tests}

Due to the limited availability, compounds 1-3 were tested for their inhibitory activity against only one cancer cell line, i.e., the human malignant melanoma cell line (A-375). The general toxicity of the isolated metabolites was assessed against the human keratinocyte cells (HaCaT). Compound 1 exhibited moderate anticancer activity against the A-375 cells $\left(\mathrm{IC}_{50}\right.$ value $\left.77.5 \mu \mathrm{M}\right)$, but it was also 
toxic towards the $\mathrm{HaCaT}$ cells $\left(\mathrm{IC}_{50}\right.$ value of $\left.39.3 \mu \mathrm{M}\right)$. The known compounds 2 and 3 did not exert anticancer or toxic effects, even at the highest test concentration of $200 \mu \mathrm{M}$.

\section{Discussion}

Pyrenochaetopsis is a ubiquitous fungal genus found in both terrestrial and marine environments [30,31]. However, the members of this genus have remained almost fully unexplored for their bioactive secondary metabolites. To our knowledge, the very first chemical study was published in 2017 by Nogawa et al. on a Pyrenochaetopsis sp. isolated from a soil sample collected in Japan [29]. This work reported wakodecalines $\mathrm{A}, \mathrm{B}$, two new tricyclic decalin derivatives with a spiro pentanone ring (C) and $N$-methylated terminal serine moiety as well as phomasetin, a known decalin compound with a terminal tetramic acid function [29]. The lack of any other investigation in the literature on chemical constituents or biological activity has initiated our interest into this unexplored fungal taxon. In a very recent study, we demonstrated that, when cultured in liquid potato dextrose medium, the algicolous Pyrenochaetopsis sp. FVE-001 produces pyrenosetins A-C, new tetracyclic decalin derivatives with good activity against malignant melanoma cells (A-375) [23]. In addition, also isolated and identified from this fungus was the known compound phomasetin [23].

The 'decalin' moiety is a common structural motif in an array of marine fungal natural products $[13,32,33]$. It has been proposed that the decalin ring serves as a primary ring system or a scaffold to form polycyclic metabolites, with bicyclic decalins being the most common [11,13,32-35]. The chemical investigation of the marine sponge-derived fungus Trichoderma harzianum in 1993 led to the isolation of the first bicyclic decalin derivative trichoharzin isolated from a marine fungus. Trichoharzin contains rare alkyl and acyl moieties [36]. So far, more than 50 decalin derivatives have been reported from marine fungi [11,13,32-37]. The marine-derived bicyclic decalin derivatives often incorporate additional ring systems, e.g., pyrone [37], cyclopentanone [13], and tetramic acid [34] to lead tricyclic [35,37], tetracyclic [13], and pentacyclic scaffolds [34]. Of all, tetramic acid represents one of the most common substituents $[13,34,38]$. Pyrenosetins A-C, which we recently reported from Pyrenochaetopsis sp. FVE-001, an endophyte of the Baltic brown alga Fucus vesiculosus, represent one of the most complex tetracyclic decalinoylspirotetramic acids reported to date [23]. Such complex decalin scaffold is rare in fungi. To our knowledge, only a few fungal genera such as Fusarium sp. [34,39], Alternaria sp. [13], Diaporthe sp. [40], and Pyrenochaetopsis sp. [23] have been reported to produce such type of unique molecules. Decalinoyltetramic acid derivatives are also intriguing for remarkable biological activities they exhibit. For example, altercrasins $\mathrm{D}$ and $\mathrm{E}$ isolated from sea-urchin-derived Alternaria sp., have shown potent activity against murine P388 leukemia, human HL-60 leukemia, and murine L1210 leukemia cell lines [13]. However, most of the decalin derivatives suffer from poor selectivity, i.e., they also possess toxicity towards non-cancerous cells. This is a common characteristic of mycotoxins [34,41].

Our previous research on pyrenosetins highlighted the importance of the side chain attached at C-13 for their bioactivity [23]; both the anticancer activity and the general toxicity were significantly reduced with the oxidation of the C-16 hydroxyl group to a ketone. Notably, wakodecalines (2 and 3 ) that lack the terminal tetramic acid moiety did not show any bioactivity against A- 375 cells, even at the highest test concentrations. This suggests that both side chain and the tetramic acid moiety are crucial for bioactivity of the decalin derivatives. Additionally, the presence of the additional tetrahydrofuran ring as found in 1 may be improving the activity against A-375 cells ( $\mathrm{IC}_{50} 77.5 \mu \mathrm{M}$ ) when compared to the anticancer activity of pyrenosetin $\mathrm{C}$ on the same cell line ( $\left.\mathrm{IC}_{50} 140.3 \mu \mathrm{M}\right)$ [23]. A previous study showed that fusarisetin $\mathrm{A}$ that possesses a tetrahydrofuran ring exhibits higher activity against the invasive breast cancer cell line MDA-MB-231 than its precursor equisetin [42].

In conclusion, a new cytotoxic pentacyclic decalinoylspirotetramic acid derivative, pyrenosetin $\mathrm{D}$ (1) and two known and non-toxic tricyclic metabolites, wakodecalines A (2) and B (3), were purified from the algicolous fungus Pyrenochaetopsis sp. To our knowledge, only fusarisetins that were isolated from Fusarium sp. possess somehow similar pentacyclic skeleton [34,39]. This is the third study 
performed on the chemical constituents of the fungal genus Pyrenochaetopsis and the first report of a pentacyclic decalin ring system from Pyrenochaetopsis species. Further investigation of the anticancer activity, selectivity, and mechanism of cytotoxic action of our metabolites might expand our knowledge of the structure-activity relationship of decalinoyltetramic acid derivatives.

\section{Materials and Methods}

\subsection{General Procedures}

FT-IR spectra were recorded on a PerkinElmer Spectrum Two FT-IR spectrometer (PerkinElmer, Boston, MA, USA). Specific rotation $\left([\alpha]_{D}\right)$ values were measured in $\mathrm{MeOH}$ on a Jasco P-2000 polarimeter (Jasco, Pfungstadt, Germany). NMR data were recorded on a Bruker AV 600 spectrometer (600 and $150 \mathrm{MHz}$ for ${ }^{1} \mathrm{H}$ and ${ }^{13} \mathrm{C}$ NMR, respectively, Bruker $($, Billerica, MA, USA). The residual solvent signals were detected in NMR spectra as internal references: $\delta_{\mathrm{H}} 1.94 / \delta_{\mathrm{C}} 118.3$ and $\delta_{\mathrm{C}} 1.3\left(\mathrm{CD}_{3} \mathrm{CN}\right)$. 4-Dimethyl-4-silapentane-1-sulfonic acid (DSS) was used as an internal standard. HRESIMS was recorded on a microTOF II-high-performance TOF-MS system (Bruker®, Billerica, MA, USA) equipped with an electrospray ionization source. Solid-phase extraction (SPE) was performed on a C18 cartridge (50 $\mu \mathrm{m}, 65 \AA$, Phenomenex, 411 Madrid Avenue, Torrance, CA, USA). HPLC separations were performed on a VWR Hitachi Chromaster system (VWR International, Allison Park, PA, USA) consisting of a 5430 diode array detector (VWR International, Allison Park, PA, USA), a 5310 column oven, a 5260 autosampler, and a 5110 pump. The eluents used for HPLC separations were milli $Q$ water (A) and $\mathrm{MeCN}(\mathrm{B})$. Routine HPLC separations were performed on a semi-preparative C18 monolithic column (Onyx, $100 \times 10 \mathrm{~mm}$, Phenomenex, Torrance, CA, USA) and an analytical synergi polar-RP $80 \AA$ LC column $(250 \times 4.6 \mathrm{~mm}$, Phenomenex, Torrance, CA, USA). The organic solvents used for chemical analysis were of HPLC grade (ITW Reagents, Germany). An in-house Arium ${ }^{\circledR}$ Water Purification Systems (Sartorius, Germany) was used for the preparation of milli $Q$ water. Solvents used in extraction, Kupchan partition, and purification (including EtOAc, $n$-hexane, $\mathrm{MeOH}$ and $\mathrm{MeCN}$ ) were purchased from VWR International GmbH (Hannover, Germany). Potato extract and dextrose that used for fungal cultivation were purchased from Sigma-Aldrich (Schnelldorf, Germany) and Merck (Darmstadt, Germany), respectively. Agar was purchased from Applichem (Darmstadt, Germany).

\subsection{Strain Identification and Cultivation}

The fungal strain Pyrenochaetopsis sp. FVE-087 (GenBank accession number: MH881502) was obtained from Fucus vesiculosus specimens that were collected in Falckenstein Beach $\left(54^{\circ} 23^{\prime} 22.6^{\prime \prime} \mathrm{N}\right.$, $10^{\circ} 11^{\prime} 26.4^{\prime \prime}$ E), Kiel Fjord, Baltic Sea, in December 2015, Germany [22]. The fungus was identified by morphological observation, analysis of the ITS1-5.8S rRNA gene-ITS2 region and by building a phylogenetic tree with 14 related strains including the Pyrenochaetopsis sp. FVE-001, using the method described in our previous work [23]. The initial cultures were maintained on potato dextrose agar plates (PDA: potato extract $4 \mathrm{~g}$, dextrose $20 \mathrm{~g}$, agar $15 \mathrm{~g}$ for $1 \mathrm{~L}, \mathrm{pH}$ 5.6). After 3 days of pre-cultivation, pieces of mycelia were cut into small segments and aseptically inoculated into an Erlenmeyer flask $(300 \mathrm{~mL}$ ) that contained $100 \mathrm{~mL}$ of potato dextrose broth media (PDM: potato extract $4 \mathrm{~g}$, dextrose $20 \mathrm{~g}$ for $1 \mathrm{~L}$; pH 5.6). After 7 days inoculation, $1 \mathrm{~mL}$ liquid seed was added into Erlenmeyer flasks (2 L), each containing $800 \mathrm{~mL}$ PDM. A $24 \mathrm{~L}$ culture broth was fermented at $22^{\circ} \mathrm{C}$ for 14 days on a rotary shaker at $120 \mathrm{rpm}$.

\subsection{Extraction and Isolation}

The culture broth was partitioned against the same volume of EtOAc twice at room temperature. The EtOAc phase was evaporated to dryness under reduced pressure to afford $17.64 \mathrm{~g}$ yellow oily extract. The extract was subjected to a modified Kupchan partition scheme to yield three subextracts, $n$-hexane $(\mathrm{KH}, 6.93 \mathrm{~g}), \mathrm{CHCl}_{3}(\mathrm{KC}, 4.57 \mathrm{~g})$, and aqueous $\mathrm{MeOH}(\mathrm{KM}, 440.5 \mathrm{mg})$. All three subextracts were tested for their bioactivity against five cancer cell lines and non-cancerous cell line HaCaT. The KC 
subextract showed high anticancer bioactivity against all five cancer cell lines ( $>84 \%$ inhibition rate at $100 \mu \mathrm{g} / \mathrm{mL}$ ) and was fractionated on a C18-SPE column eluting with $10 \%$ stepwise gradient of $\mathrm{MeOH}$ in water (0-100\%) to afford 11 fractions (F0-F10). Anticancer bioactivity was tracked to fractions F7-F9 (Table S6). The fraction 7 (F7, $138 \mathrm{mg}$ ) was subjected to semi-preparative RP-HPLC equipped with an Onyx monolithic $\mathrm{C} 18$ column. Elution with a gradient $\mathrm{MeCN}: \mathrm{H}_{2} \mathrm{O}$ mixture (25-35\% MeCN over $30 \mathrm{~min}$, flow $3.0 \mathrm{~mL} / \mathrm{min}$ ) yielded eight subfractions (F7-1 to F7-8). The F7-7 $(10.8 \mathrm{mg})$ was further purified by RP-HPLC on an analytical synergi polar-RP $80 \AA$ A column eluting with $\mathrm{MeCN}: \mathrm{H}_{2} \mathrm{O}(52 \%$ isocratic MeCN over $19 \mathrm{~min}$, flow $1.0 \mathrm{~mL} / \mathrm{min})$ to yield wakodecaline $\mathrm{B}\left(3,2.4 \mathrm{mg}, \mathrm{t}_{\mathrm{R}} 8.8 \mathrm{~min}\right)$ and pyrenosetin $\mathrm{D}$ $\left(\mathbf{1}, 1.2 \mathrm{mg}, \mathrm{t}_{\mathrm{R}} 10.3 \mathrm{~min}\right)$. The subfraction 8 (F8, 369.6 mg) was chromatographed by RP-HPLC equipped with Onyx monolithic $\mathrm{C} 18$ column using $\mathrm{MeCN}: \mathrm{H}_{2} \mathrm{O}$ mixtures $(40 \%$ isocratic MeCN over $28 \mathrm{~min}$ and gradual increase to $60 \% \mathrm{MeCN}$ by $40 \mathrm{~min}$, flow $3.0 \mathrm{~mL} / \mathrm{min}$ ) to yield 14 subfractions (F8-1 to 14). Wakodecaline A (2) was tracked to F8-3 $(7 \mathrm{mg})$. This fraction was subjected to RP-HPLC on an analytical synergi polar-RP $80 \AA \mathrm{LC}$ column using an isocratic mixture of $\mathrm{MeCN}: \mathrm{H}_{2} \mathrm{O}$ (45:55) (flow $1.0 \mathrm{~mL} / \mathrm{min})$ to yield wakodecaline $\mathrm{A}\left(2,2.9 \mathrm{mg}, \mathrm{t}_{\mathrm{R}} 9.5 \mathrm{~min}\right)$.

Pyrenosetin D (1): Colorless oil; $[\alpha]^{20}{ }_{D}-56$ (c 0.10, MeOH); IR (oil) $v_{\max } 3226-3560,2947,2921,1734$, $1679,1460,1406,1377,1159,1064 \mathrm{~cm}^{-1} .{ }^{1} \mathrm{H}$ NMR $\left(\mathrm{CD}_{3} \mathrm{CN}, 600 \mathrm{MHz}\right)$ and ${ }^{13} \mathrm{C} \mathrm{NMR}\left(\mathrm{CD}_{3} \mathrm{CN}, 150 \mathrm{MHz}\right)$ are shown in Table 1; HR-ESIMS found $m / z 446.2520[\mathrm{M}+\mathrm{H}]^{+}, \mathrm{C}_{25} \mathrm{H}_{36} \mathrm{NO}_{6}$, calculated for 446.2537.

\subsection{Computational Details}

Conformational search for $\mathbf{1}$ and $5^{\prime}$-epi-1 was based on a 10-ns molecular dynamics (MD) simulation at $600 \mathrm{~K}$ as previously described [43]. The MD simulation generated 101 and 102 different conformers for $\mathbf{1}$ and $5^{\prime}$-epi-1, respectively, within $5 \mathrm{kcal} / \mathrm{mol}$ from the lowest energy conformer. Optimizations of geometries from MD were performed using density functional theory (DFT) with the Gaussian 16 program [44], the B3LYP functional, the 6-31G(d,p) basis set, and the SMD model for the solvent, ACN. This resulted in 15 and 17 conformers for 1 and $5^{\prime}$-epi-1, respectively, within $3 \mathrm{kcal} / \mathrm{mol}$ from the lowest energy conformer. Finally, these conformers were further optimized at the B3LYP/TZVP/SMD level of theory, giving a final set of 10 significantly populated (population $>1 \%$ at $298 \mathrm{~K}$ ) conformers for $\mathbf{1}$ and 11 significantly populated conformers for $5^{\prime}$-epi-1. Vibrational frequency analysis revealed no imaginary frequencies, confirming that all conformers were in a true energy minimum. The Cartesian coordinates and relative energies of the conformers are reported in Tables S1 and S2. These conformational ensembles were used for all the subsequent calculations.

NMR isotropic shieldings of $\mathbf{1}$ and $5^{\prime}$-epi-1 were calculated using WP04/aug-cc-pVDZ/PCM for ${ }^{1} \mathrm{H}$ and mPW1PW91/6-311+G(2d,p) for ${ }^{13} \mathrm{C}$, which have been shown to be most accurate levels of theory, among those tested, for NMR data acquired in $\mathrm{CD}_{3} \mathrm{CN}$ [45]. Average shieldings were obtained by Boltzmann statistics based on internal energies of conformers. Finally, shieldings were scaled to chemical shifts using linear regression [25]. The results are reported in Tables S3 and S4. Coupling constants were calculated at the B3LYP/6-31G(d,p) level and using the keyword "mixed", which augments the basis set for the calculation of the Fermi Contact term, and averaged by Boltzmann statistics. The results are reported in Table S4.

Optical rotations of DFT-optimized conformer of $\mathbf{1}$ were calculated using TDDFT at the B3LYP/TZVP/PCM $(\mathrm{MeOH})$ level; the results can be found in Table S1. The Boltzmann mean of individual optical rotations gave $[\alpha]_{\mathrm{D}}=-105$.

\subsection{Biological Assays}

The bioactivity tests were performed as described previously [23]. The crude extract, the subextracts and the SPE fractions of the KC subextract were tested in vitro against five human cancer cell lines: colorectal adenocarcinoma cell line HT-29 (DSMZ, Braunschweig, Germany), malignant melanoma cell line A-375 (CLS, Eppelheim, Germany), colon cancer cell line HCT-116 (DSMZ, Braunschweig, Germany), lung carcinoma cell line A-549 (CLS, Eppelheim, Germany), human breast cancer line MDA-MB-231 (CLS, Eppelheim, Germany), as well as for the non-cancerous human keratinocyte 
line HaCaT (CLS, Eppelheim, Germany) at a concentration of $100 \mu \mathrm{g} / \mathrm{mL}$. The bioactivity of the extracts was evaluated by monitoring the metabolic activity using the CellTiterBlue Cell Viability Assay (Promega, Mannheim, Germany). HT-29 and HaCaT cells were cultivated in RPMI medium, A-549 and MDA-MB-231 cells in DMEM:Ham's F12 medium (1:1) supplemented with 15mM HEPES and A-375 and HCT-116 cells in DMEM medium supplemented with $4.5 \mathrm{~g} / \mathrm{L}$ D-Glucose and $110 \mathrm{mg} / \mathrm{L}$ sodium pyruvate. All media were supplemented with L-glutamine, $10 \%$ fetal bovine serum, $100 \mathrm{U} / \mathrm{mL}$ penicillin, and $100 \mathrm{mg} / \mathrm{mL}$ streptomycin. The cultures were maintained at $37^{\circ} \mathrm{C}$ under a humidified atmosphere and $5 \% \mathrm{CO}_{2}$. The cell lines were transferred every 3 or 4 days. For the experimental procedure, the cells were seeded in 96-well plates at a concentration of 10,000 cells per well. A stock solution of $40 \mathrm{mg} / \mathrm{mL}$ in DMSO was prepared for each extract. After $24 \mathrm{~h}$ incubation, the medium was removed from the cells and $100 \mu \mathrm{L}$ fresh medium containing the test samples was added. Each sample was prepared in duplicate once. Doxorubicin as a standard therapeutic drug was used as a positive control, $0.5 \%$ DMSO and growth media were used as negative controls. Following compound addition, plates were cultured at $37^{\circ} \mathrm{C}$ for $24 \mathrm{~h}$. Afterward, the assay was performed according to the manufacturer's instructions and measured using the microplate reader Tecan Infinite M200 at excitation $560 \mathrm{~nm}$ and emission of $590 \mathrm{~nm}$. For determination of $\mathrm{IC}_{50}$ values, a dilution series of the extracts were prepared and tested, as described before for the crude extract. The $\mathrm{IC}_{50}$ values were calculated by Excel as the concentration that shows 50\% inhibition of the viability based on a negative control (no compound) and compared with the positive control (doxorubicin).

Supplementary Materials: The following are available online at http://www.mdpi.com/1660-3397/18/6/281/s1; NMR, HRESIMS, and FT-IR spectra of compound 1. Tables with detailed information of computational results.

Author Contributions: Design of the work, D.T. and B.F.; extraction, purifications of compounds, B.F.; data analysis, B.F., F.L., P.D. and D.T.; computational studies, L.G. and A.M.; strain identification M.B. and B.F.; writing the original manuscript, B.F., P.D., D.T.; supervision, D.T. All authors have read and agreed to the published version of the manuscript.

Funding: B.F. is the recipient of a China Scholarship Council Ph.D. scholarship. A.M was supported by Regione Campania, PO FESR 2014-2020, O.S. 1.2, Project "Campania Oncoterapie" No. B61G18000470007.

Acknowledgments: We are grateful to Arlette Wenzel-Storjohann and Jana Heumann for performing anticancer assays. We acknowledge financial support by DFG within the funding programm Open Access Publizieren.

Conflicts of Interest: The authors declare no conflict of interest.

\section{References}

1. Flewelling, A.J.; Johnson, J.A.; Gray, C.A. Isolation and bioassay screening of fungal endophytes from North Atlantic marine macroalgae. Bot. Mar. 2013, 56, 287-297. [CrossRef]

2. Zuccaro, A.; Schoch, C.L.; Spatafora, J.W.; Kohlmeyer, J.; Draeger, S.; Mitchell, J.I. Detection and identification of fungi intimately associated with the brown seaweed Fucus serratus. Appl. Environ. Microbiol. 2008, 74, 931-941. [CrossRef] [PubMed]

3. Egan, S.; Harder, T.; Burke, C.; Steinberg, P.; Kjelleberg, S.; Thomas, T. The seaweed holobiont: Understanding seaweed-bacteria interactions. FEMS Microbiol. Rev. 2013, 37, 462-476. [CrossRef] [PubMed]

4. Zhang, P.; Li, X.; Wang, B.-G. Secondary metabolites from the marine algal-derived endophytic fungi: Chemical diversity and biological activity. Planta Med. 2016, 82, 832-842. [CrossRef] [PubMed]

5. Son, B.W.; Choi, J.S.; Kim, J.C.; Nam, K.W.; Kim, D.-S.; Chung, H.Y.; Kang, J.S.; Choi, H.D. Parasitenone, a new epoxycyclohexenone related to gabosine from the marine-derived fungus Aspergillus parasiticus. J. Nat. Prod. 2002, 65, 794-795. [CrossRef] [PubMed]

6. Almeida, C.; Elsaedi, S.; Kehraus, S.; König, G.M. Novel bisabolane sesquiterpenes from the marine-derived fungus Verticillium tenerum. Nat. Prod. Commun. 2010, 5, 507-510. [CrossRef] [PubMed]

7. Cui, C.-M.; Li, X.-M.; Meng, L.; Li, C.-S.; Huang, C.-G.; Wang, B.-G. 7-Nor-ergosterolide, a pentalactone-containing norsteroid and related steroids from the marine-derived endophytic Aspergillus ochraceus EN-31. J. Nat. Prod. 2010, 73, 1780-1784. [CrossRef]

8. Komatsu, K.; Shigemori, H.; Kobayashi, J. Dictyonamides A and B, new peptides from marine-derived fungus. J. Org. Chem. 2001, 66, 6189-6192. [CrossRef] 
9. Du, F.-Y.; Li, X.-M.; Li, C.-S.; Shang, Z.; Wang, B.-G. Cristatumins A-D, new indole alkaloids from the marine-derived endophytic fungus Eurotium cristatum EN-220. Bioorg. Med. Chem. Lett. 2012, 22, 4650-4653. [CrossRef]

10. Abdel-Lateff, A.; Klemke, C.; König, G.M.; Wright, A.D. Two new xanthone derivatives from the algicolous marine fungus Wardomyces anomalus. J. Nat. Prod. 2003, 66, 706-708. [CrossRef]

11. Li, G.; Kusari, S.; Spiteller, M. Natural products containing 'decalin' motif in microorganisms. Nat. Prod. Rep. 2014, 31, 1175-1201. [CrossRef] [PubMed]

12. Sobolevskaya, M.P.; Leshchenko, E.V.; Hoai, T.P.T.; Denisenko, V.A.; Dyshlovoy, S.A.; Kirichuk, N.N.; Khudyakova, Y.V.; Kim, N.Y.; Berdyshev, D.V.; Pislyagin, E.A.; et al. Pallidopenillines: Polyketides from the alga-derived fungus Penicillium thomii Maire KMM 4675. J. Nat. Prod. 2016, 79, 3031-3038. [CrossRef] [PubMed]

13. Yamada, T.; Tanaka, A.; Nehira, T.; Nishii, T.; Kikuchi, T. Altercrasins A-E, decalin derivatives, from a sea-urchin-derived Alternaria sp.: Isolation and structural analysis including stereochemistry. Mar. Drugs 2019, 17, 218. [CrossRef] [PubMed]

14. Jenkins, K.M.; Toske, S.G.; Jensen, P.R.; Fenical, W. Solanapyrones E-G, antialgal metabolites produced by a marine fungus. Phytochemistry 1998, 49, 2299-2304. [CrossRef]

15. Nguyen, H.P.; Zhang, D.; Lee, U.; Kang, J.S.; Choi, H.D.; Son, B.W. Dehydroxychlorofusarielin B, an antibacterial polyoxygenated decalin derivative from the marine-derived fungus Aspergillus sp. J. Nat. Prod. 2007, 70, 1188-1190. [CrossRef] [PubMed]

16. Nogawa, T.; Kawatani, M.; Uramoto, M.; Okano, A.; Aono, H.; Futamura, Y.; Koshino, H.; Takahashi, S.; Osada, H. Pyrrolizilactone, a new pyrrolizidinone metabolite produced by a fungus. J. Antibiot. 2013, 66, 621-623. [CrossRef]

17. Osterhage, C.; Kaminsky, R.; König, G.M.; Wright, A.D. Ascosalipyrrolidinone A, an antimicrobial alkaloid, from the obligate marine fungus Ascochyta salicorniae. J. Org. Chem. 2000, 65, 6412-6417. [CrossRef]

18. Yamada, T.; Mizutani, Y.; Umebayashi, Y.; Inno, N.; Kawashima, M.; Kikuchi, T.; Tanaka, R. Tandyukisin, a novel ketoaldehyde decalin derivative, produced by a marine sponge-derived Trichoderma harzianum. Tetrahedron Lett. 2014, 55, 662-664. [CrossRef]

19. Singh, S.B.; Zink, D.L.; Goetz, M.A.; Dombrowski, A.W.; Polishook, J.D.; Hazuda, D.J. Equisetin and a novel opposite stereochemical homolog phomasetin, two fungal metabolites as inhibitors of HIV-1 integrase. Tetrahedron Lett. 1998, 39, 2243-2246. [CrossRef]

20. Alfatafta, A.A.; Gloer, J.B.; Scott, J.A.; Malloch, D. Apiosporamide, a new antifungal agent from the coprophilous fungus Apiospora montagnei. J. Nat. Prod. 1994, 57, 1696-1702. [CrossRef]

21. Duong, T.-H.; Nguyen, H.-H.; Le, T.-T.; Tran, T.-N.; Sichaem, J.; Nguyen, T.-T.; Nguyen, T.-P.; Mai, D.-T.; Nguyen, H.-H.; Le, H.-D. Subnudatones A and B, new trans-decalin polyketides from the cultured lichen mycobionts of Pseudopyrenula subnudata. Fitoterapia 2020, 142, 104512-104526. [CrossRef]

22. Fan, B.; Parrot, D.; Blümel, M.; Labes, A.; Tasdemir, D. Influence of OSMAC-based cultivation in metabolome and anticancer activity of fungi associated with the brown alga Fucus vesiculosus. Mar. Drugs 2019, 17, 67. [CrossRef]

23. Fan, B.; Dewapriya, P.; Li, F.; Blümel, M.; Tasdemir, D. Pyrenosetins A-C, new decalinoylspirotetramic acid derivatives isolated by bioactivity-based molecular networking from the seaweed-derived fungus Pyrenochaetopsis sp. FVE-001. Mar. Drugs 2020, 18, 47. [CrossRef] [PubMed]

24. Carey, F.A.; Sundberg, R.J. Advanced Organic Chemistry, 3rd ed.; Plenum Press: New York, NY, USA, 1990; p. 158.

25. Moosmann, P.; Ueoka, R.; Grauso, L.; Mangoni, A.; Morinaka, B.I.; Gugger, M.; Piel, J. Cyanobacterial ent-sterol-like natural products from a deviated ubiquinone pathway. Angew. Chem. Int. Ed. Engl. 2017, 56, 4987-4990. [CrossRef]

26. Grimblat, N.; Zanardi, M.M.; Sarotti, A.M. Beyond DP4: An improved probability for the stereochemical assignment of isomeric compounds using quantum chemical calculations of NMR shifts. J. Org. Chem. 2015, 80, 12526-12534. [CrossRef] [PubMed]

27. Ciminiello, P.; Dell' Aversano, C.; Dello Iacovo, E.; Fattorusso, E.; Forino, M.; Grauso, L.; Tartaglione, L. Stereochemical studies on ovatoxin-a. Chem. Eur. J. 2012, 18, 16836-16843. [CrossRef]

28. Grauso, L.; Teta, R.; Esposito, G.; Menna, M.; Mangoni, A. Computational prediction of chiroptical properties in structure elucidation of natural products. Nat. Prod. Rep. 2019, 36, 1005-1030. [CrossRef] [PubMed] 
29. Nogawa, T.; Kato, N.; Shimizu, T.; Okano, A.; Futamura, Y.; Takahashi, S.; Osada, H. Wakodecalines A and B, new decaline metabolites isolated from a fungus Pyrenochaetopsis sp. RK10-F058. J. Antibiot. 2017, 71, 123-128. [CrossRef] [PubMed]

30. De Gruyter, J.; Woudenberg, J.H.C.; Aveskamp, M.M.; Verkley, G.J.M.; Groenewald, J.Z.; Crous, P.W. Redisposition of Phoma-like anamorphs in Pleosporales. Stud. Mycol. 2013, 75, 1-36. [CrossRef]

31. De Gruyter, J.; Woudenberg, J.H.C.; Aveskamp, M.M.; Verkley, G.J.M.; Groenewald, J.Z.; Crous, P.W. Systematic reappraisal of species in Phoma section Paraphoma, Pyrenochaeta and Pleurophoma. Mycologia 2010, 102, 1066-1081. [CrossRef]

32. Klemke, C.; Kehraus, S.; Wright, A.D.; König, G.M. New secondary metabolites from the marine endophytic fungus Apiospora montagnei. J. Nat. Prod. 2004, 67, 1058-1063. [CrossRef] [PubMed]

33. Wu, B.; Wiese, J.; Labes, A.; Kramer, A.; Schmaljohann, R.; Imhoff, J.F. Lindgomycin, an unusual antibiotic polyketide from a marine fungus of the Lindgomycetaceae. Mar. Drugs 2015, 13, 4617-4632. [CrossRef] [PubMed]

34. Zhao, D.; Han, X.; Wang, D.; Liu, M.; Gou, J.; Peng, Y.; Liu, J.; Li, Y.; Cao, F.; Zhang, C. Bioactive 3-decalinoyltetramic acids derivatives from a marine-derived strain of the fungus Fusarium equiseti D39. Front. Microbiol. 2019, 10, 1285. [CrossRef]

35. Afiyatullov, S.S.; Leshchenko, E.V.; Berdyshev, D.V.; Sobolevskaya, M.P.; Antonov, A.S.; Denisenko, V.A.; Popov, R.S.; Pivkin, M.V.; Udovenko, A.A.; Pislyagin, E.A.; et al. Zosteropenillines: Polyketides from the marine-derived fungus Penicillium thomii. Mar. Drugs 2017, 15, 46. [CrossRef] [PubMed]

36. Kobayashi, M.; Uehara, H.; Matsunami, K.; Aoki, S.; Kitagawa, I. Trichoharzin, a new polyketide produced by the imperfect fungus Trichoderma harzianum separated from the marine sponge Micale cecilia. Tetrahedron Lett. 1993, 34, 7925-7928. [CrossRef]

37. Ma, Y.; Li, J.; Huang, M.; Liu, L.; Wang, J.; Lin, Y. Six new polyketide decalin compounds from mangrove endophytic fungus Penicillium aurantiogriseum 328\#. Mar. Drugs 2015, 13, 6306-6318. [CrossRef] [PubMed]

38. Yamada, T.; Kikuchi, T.; Tanaka, R. Altercrasin A, a novel decalin derivative with spirotetramic acid, produced by a sea urchin-derived Alternaria sp. Tetrahedron Lett. 2015, 56, 1229-1232. [CrossRef]

39. Jang, J.-H.; Asami, Y.; Jang, J.-P.; Kim, S.-O.; Moon, D.O.; Shin, K.-S.; Hashizume, D.; Muroi, M.; Saito, T.; Oh, H. Fusarisetin A, an acinar morphogenesis inhibitor from a soil fungus, Fusarium sp. FN080326. J. Am. Chem. Soc. 2011, 133, 6865-6867. [CrossRef]

40. Pornpakakul, S.; Roengsumran, S.; Deechangvipart, S.; Petsom, A.; Muangsin, N.; Ngamrojnavanich, N.; Sriubolmas, N.; Chaichit, N.; Ohta, T. Diaporthichalasin, a novel CYP3A4 inhibitor from an endophytic Diaporthe sp. Tetrahedron Lett. 2007, 48, 651-655. [CrossRef]

41. Pitt, J.I.; Miller, J.D. A concise history of mycotoxin research. J. Agric. Food Chem. 2017, 65, 7021-7033. [CrossRef]

42. Xu, J.; Caro-Diaz, E.J.E.; Lacoske, M.H.; Hung, C.-I.; Jamora, C.; Theodorakis, E.A. Fusarisetin A: Scalable total synthesis and related studies. Chem. Sci. 2012, 3, 3378-3386. [CrossRef] [PubMed]

43. Grauso, L.; Li, Y.; Scarpato, S.; Shulha, O.; Rárová, L.; Strnad, M.; Teta, R.; Mangoni, A.; Zidorn, C. Structure and conformation of zosteraphenols, tetracyclic diarylheptanoids from the seagrass Zostera marina: An NMR and DFT Study. Org. Lett. 2020, 22, 78-82. [CrossRef] [PubMed]

44. Frisch, M.J.; Trucks, G.W.; Schlegel, H.B.; Scuseria, G.E.; Robb, M.A.; Cheeseman, J.R.; Scalmani, G.; Barone, V.; Petersson, G.A.; Nakatsuji, H.; et al. Gaussian 16. Revision C.01.; Gaussian, Inc.: Wallingford, CT, USA, 2019.

45. Pierens, G.K. ${ }^{1} \mathrm{H}$ and ${ }^{13} \mathrm{C}$ NMR scaling factors for the calculation of chemical shifts in commonly used solvents using density functional theory. J. Comput. Chem. 2014, 35, 1388-1394. [CrossRef] [PubMed]

(C) 2020 by the authors. Licensee MDPI, Basel, Switzerland. This article is an open access article distributed under the terms and conditions of the Creative Commons Attribution (CC BY) license (http://creativecommons.org/licenses/by/4.0/). 